\title{
THE PROBLEM OF RESOURCE CONSERVATION WITHIN THE LIFE CYCLE OF NONWOVEN MATERIALS
}

\begin{abstract}
Inna Tkachenko
Master's degree student of Faculty of Chemical and Biopharmaceutical Technologies Kyiv National University of Technologies and Design
\end{abstract} ORCID ID: 0000-0003-0370-0283

Nataliia Gudkova

$\mathrm{PhD}$ in Linguistics, Associate Professor of the Foreign Languages Department Kyiv National University of Technologies and Design

UKRAINE

Intensive development of scientific and technological progress and rapid population growth over the past century have led to the fact that the world has accumulated a huge amount of unused waste [1]. At present, textile waste is generated at all light industry enterprises. Such wastes are generated in huge quantities and are not accepted by procurement organizations, but are taken out for disposal, thereby deteriorating the ecological condition of the country. Therefore, there is an important scientific and technical problem, which is to develop technological processes using textile waste. In order to solve this problem, it is extremely important to gain an insight into the special technical and technological solutions in this field. They are the combining of different methods of forming and bonding fibrous webs, additional processing and processing of nonwovens, as well as the creation of modern small plants for the production of goods that are in limited demand.

Nonwovens are products and fabrics manufactured from all kinds of materials such as fibers, threads and others without the use of weaving and spinning production. These are products of small thickness, relatively large width and indefinitely long length, made of one or several layers of textile materials (fibrous wadding, threads and low-density fabrics, etc.) and fastened in various ways. Nonwovens are fabric-like in appearance.

Nonwovens are composed of two elements, one of them serves as a base, the other as a binder. The base element is the base of the nonwoven fabric. A fibrous canvas, a filament system, a polymer film having a fibrous structure is used as a base element, fabrics or combinations of these materials. As a binder, which is used to fasten the base element, threads, fibers from a base, fibrous canvas, polymeric substances (polyethylene, rubbers), chemical fibers with a low melting point can be used [2].

The 1930s are considered the beginning of the era of nonwovens. The first images were created in Europe. These were canvases of viscose fibers held together by chemical binders. Somewhat later, other methods of their production were mastered, differing both in the type of raw material and in the method of bonding. Interest in nonwovens arose instantly. It turned out that the formation of textile fabrics by non-traditional methods and the possibility of using all known types of fibers in them both individually and in various combinations, which are impossible with the classical methods of obtaining fabrics and knitwear, along with the properties inherent in woven products, give them completely new qualities. The main operational 
properties of nonwovens are their lightness and strength, which are perfectly complemented by a low price, ease of use, frost and fire resistance. Nonwovens have a very wide range of temperatures of use - from $-60^{\circ} \mathrm{C}$ to $+100^{\circ} \mathrm{C}$ [3].

Non-woven production has a lot of advantages, including the use of raw materials of both natural fibers (cotton, linen, woolen) and chemical ones (viscose, polyester, polyamide, polyacrylonitrile, polypropylene). Secondary fibrous raw materials (fibers reclaimed from rags and rags) and short-fiber waste from chemical and other industries are among the raw stock as well. The basis of non-woven fabrics are fibrous webs, layers of threads, fabrics and knitted fabrics, polymer films, nets. Often, to increase the strength of the fibrous web, a frame is placed on its surface or between the layers in the form of a transverse system of yarns, a mesh of warp and weft yarns, rare fabric, polymer film [3].

Compared to traditional production methods in textile industry, which are weaving and spinning, the production of nonwovens has the following predominant features: 1) the use of cheap and less scarce raw materials; 2) the simplicity of technology including a reduction in the number of technological stages and intensification of production; 3) an increase in equipment productivity; 4) less capital and labor costs; 5) a reduction in the consumption of material resources; 6) a variety of product ranges; 7) the possibility of rational use of various raw materials; 8) lower production costs; 9) the possibility of maximum automation of production which implies the creation of production lines and automatic factories; 10) good performance properties of nonwovens. Therefore, nonwovens have become one of the main types of modern textile products, although their large-scale industrial production appeared only in the $40 \mathrm{~s}$. of the XX century. The world production of nonwovens in 1985 was about 16 billion $\mathrm{m}^{2}$, with the USA accounting for $59 \%$ of all nonwovens produced in capitalist countries, $32 \%$ in Western Europe, and $9 \%$ in Japan [4].

A feature of the production of nonwovens is the use of low-quality raw materials, short fibers up to $3 \mathrm{~mm}$ from production waste. Raw materials are processed at a small number of operations, so the preparation of raw materials is carried out very carefully. In the process of this operation, the fibers are loosened and cleaned from plant and mineral impurities, components are selected for obtaining a homogeneous mixture of fibers, prepare the fibrous raw material for canvas formation and further processing [2]. The properties of nonwovens depend on their structure and production method, the nature of the raw materials. There are following technological basic operations for the production of nonwovens materials:

- the preparation of raw materials (cleaning from impurities, loosening, mixing fibers, preparing binders, chemical solutions (hardeners, swelling agents, surfactants, etc.), and rewinding threads and yarns;

- the formation of a fibrous base, consisting of filament systems and canvas (canvas formation). Low-density fabrics, non-woven fabrics and other fabrics can be used as a frame;

- the bonding into a single system of a fibrous base or frame (direct production of nonwoven material) [2];

- the finishing works (washing, drying, bleaching, dyeing) related to non-woven materials to give it certain properties such as color, fluffiness, etc.

The finish of the nonwoven fabric is the same as the finish of the fabrics. At the same time, the increased extensibility of nonwoven fabrics is taken into account: all finishing operations proceed at minimum tension of canvases. Cotton non-woven fabrics are boiled and bleached. Semi-woolen nonwoven fabrics are rolled or nailed. 
Non-woven fabrics are painted, a pattern is applied to them, and subjected to final finishing. The final finishing of nonwovens means the process of imparting the necessary properties to nonwovens, such as waterproofing, airtightness, nonflammability, resistance to break, etc. In order to impart certain properties to the material, they resort to the following processes: impregnation with special compounds, which as a rule occurs by immersing the material in a special bath with further drying of the material in special ovens [3].

Development trends in the field of finishing of technical textile materials are determined by the general directions of the development of the relevant industries, including:

- the use of new types of fibers and textile fabrics of new structures, which often contain non-textile components, such as polymer films or coatings;

- satisfaction of new and/or a combination of several requirements to the functional properties of textile materials or products made of them;

- creation of products of a special form or with the specific sizes;

- development and implementation of new test methods to verify the quality and functional properties of materials and products;

- increasing the value of products through, in particular, more careful processing of their color and design.

There are five ways to form a web: mechanical, aerodynamic, electrostatic, hydrodynamic and fiber-forming.

The essence of the mechanical method of canvas formation is to form a web of several layers of fleece obtained from combing machines and devices. This method uses hat, roller combing machines [2]. In the mechanical method, the base is obtained by laying in different directions the layers of fibers coming out of the combing machine [5]. This method is characterized by good loosening and mixing of different fibers, as well as the possibility of processing fibers of heterogeneous quality [6].

The essence of the aerodynamic method is to form a web of pre-loose fibers moving in the air flow. This method is the most promising because it allows you to get canvases with a chaotic, equable in all directions, and oriented arrangement of threads [5].

The essence of the electrostatic method of canvas formation is based on the properties of fibers to accumulate static electricity. By controlling the location of the fibers on a special transport, you can get materials with good dielectric properties. This method uses special devices [2]. In the electrostatic method, the fibers and the conveyor are communicated with opposite charges, as a result of which they are attracted to each other and create a uniform layer of the canvas [3].

The hydrodynamic method of canvas formation, which is sometimes called wet or paper-forming, is realized by means of an aqueous medium, which is at the same time a dispersion medium for fiber and is transported by an agent to move it into the zone of fabric formation [7]. The hydrodynamic method involves obtaining nonwoven materials without the use of fibers. Nonwoven materials are formed by the formation of condensation structures from solutions or aerosols of polymers, curing foam, polymerization of monomers in a medium containing filler, which are washed out, and more.

The fiber-forming method of the fabric is obtained by laying on the mesh surface of the conveyor continuous fibers (threads) immediately after their formation from the melt or polymer solution. The fibrous warp of yarns is formed by laying several layers of yarn or finished chemical yarns by arrangement, for example in the form of a grid, or chaotically [5]. 
The most popular in the Ukrainian market is still importing products, which directly indicates the answer between its evaluation and quality. Importing countries, such as Uzbekistan, China, Germany, France, Turkey, ensure the environmental friendliness and quality of their products. Nowadays these are the main criteria that Ukrainian consumers prefer when choosing products in a crisis of environmental conditions. Domestic manufacturers for the manufacture of nonwovens for various functional purposes use mainly synthetic fibres, textile waste and importing raw materials [8]. Only $40 \%$ of non-woven materials of domestic production are concentrated on the domestic market, and $60 \%$ are mainly imported products and products of illegal origin. The situation is further complicated by the fact that almost $80 \%$ of nonwovens manufactured by Ukrainian manufacturers are intended for sale in foreign, mostly European, markets [5].

Nonwovens offer new opportunities to address global challenges related to climate change, the use of local raw materials and the provision of their production. The theme of resource conservation runs through all stages of the life cycle of nonwovens, from the raw materials used to make them to the disposal of used products.

\section{References:}

[1] Воронцов, А. И. (1989). Охрана природы. М.: Агропромиздат.

[2] Коломейцева, Э. А. (2011). Новые способы получения льносодержащих нетканых материалов со специальными свойствами. Текстильная промышленность, (2), 40-45.

[3] Трещалин, Ю. М. (2015). Композиционные материалы на основе нетканых полотен. М.: МГУ.

[4] Собкевич, О. В. (2011). Реструктуризація промисловості України у процесі посткризового відновлення. К.: НІСД.

[5] Горчакова, В. М. (2020). Нетканые материалы. Retrieved from: http://www.chemport.ru/data/chemipedia/article_2407.html

[6] Мухамеджанов, Г. К. (2016). Нетканый технический текстиль: состояние, проблемы, тенденции и перспективы. Российский рынок технического текстиля и нетканых материалов: наука, производство в современных экономических условиях: сборник докладов участников Первого Международного научно-практического симпозиума (с. 36-46). 25 февраля 2016, М.: Экспоцентр.

[7] Производство нетканых материалов из вторичных волокон. (2020). Retrieved from: https://ztbo.ru/otbo/lit/pererabotka-promishlennix-otxodov/proizvodstvo-netkanykh-materialov-iz-vtorichnykh-volokon

[8] Живетин, В.В.(2000). Масличный лён и его комплексное развитие. М.: ЦНИИЛКА. 